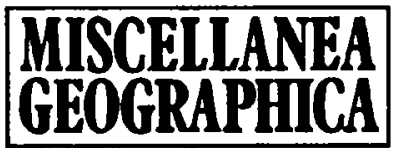

WARSZAWA 1994 Vol. 6

Andrzej Wieloński

\title{
THE ROLE OF SMALL-SCALE INDUSTRY IN STRUCTURAL TRANSFORMATION OF POLAND'S ECONOMY
}

In 1990 Poland embarked upon a road of transition from the centrally planned economy to the market economy, thus trying to join the processes characteristic of the world economy.

In industry this entails the necessity to raise its efficiency, competition and innovation ability through: privatization, aimed at expanding the private sector at the cost of state-owned enterpises, and restructuring, aimed at promotion of modern sector (high technology industries) at the cost of the traditional sector (especially mining, classical steel production and the preliminary stages of the chemical raw material processing).

It is of special importance in view of the signing of the treaty on association with the European Community.

However, the extent of changes in Polish industry is limited by scarcity of financial means - private and state alike. The lack of the former prevents private capital from large-scale investment in privatization; the lack of the state financial means precludes the use of classical tools of industrial policy (flexible credit and tax policy) giving priority to high technology industries.

As a result, in 1992 the share of private sector in total industrial output amounted to $28 \%$, while the share of high technology industries totalled $4 \%$.

Likewise, the branch structure of high technology industries in Poland is disadvantageous. As compared to the EC countries, where their share in total industrial output ranges from 14 to $20 \%$, it is characterized by insufficient development of electronics, being currently the material base for transformation, both in industry and in all the remaining sectors of the economy. This is indicated by its nearly five times lower share in creation of GDP in Poland, as compared to highly developed countries.

The prospects for acceleration of privatization and restructuring are provided by development of small-scale industry. ${ }^{1 .}$

In Poland, the share of small-scale industry in total employment in industry does not exceed $30 \%$. It is only in five sectors that small-scale in-

\footnotetext{
1 According to the EC classification, enterprises employing up to 99 persons are called small, while those employing from 100 to 499 persons are termed medium-sized. Small and medium-sized industrial enterprises form small-scale industry.
} 
dustry concentrates more than half of the employees. These are: fodder and utilization industry (80\%), building materials industry (63\%), printing industry (63\%), clothing industry (61\%), and the remaining industrial sectors encompassing i.a. manufacturing of toys, office materials, and school equipment $(68 \%)$.

This is the result of the hitherto industrial policy based on the assumption that only big enterprises enable the liquidation of delay in industrialization of the country, and dissemination of the conception of small-scale industry as the economic activity representing traditional industrial sectors.

This policy - though slightly changed - was pursued in Poland until the second half of the 1980s.

For the sake of comparison it should be added that the share of smallscale industry in total employment in the EC industry amounts to $57 \%$, including Spain $-90 \%$, Holland $-78 \%$, Italy $-73 \%$, Germany $-48 \%$, and Great Britain - 47\%. In these countries, small-scale industry is regarded as a source of constant renewal of industry, economic development and high competitive power. It is largely the result of active support granted to small and medium-sized enterprises.

In Poland in the early 1990 s administrative and legal barriers were lifted (i.a. by simplifying considerably the formalities connected with the undertaking of economic activity) which had been created by the previous economic system to the development of private entrepreneurship. This has resulted in the expansion of private initiative and establishment of over 600 thousand new enterprises, employing $1.6 \mathrm{mln}$ people and generating some 25\% of GDP outside agriculture. Most of them represent trade and catering, and their establishment does not entail great capital outlays and modern technology, as well as building enterprises. Only one-fourth of the newly established enterprises is involved in industrial output.

The emergence of a strong small-scale industrial sector in Poland, representing traditional as well as high technology industries, is conditioned by the creation of the system of economic incentives (tax exemptions, credit facilities, aid in acquiring plots or premises indispensable for their operation etc.) to promote growth of small and medium-sized industrial enterprises. It should be accompanied by utilization of other possibilities to speed up privatization and restructuring of industry, and especially by:

- introduction - alongside the programme of universal privatization - of instalment purchase of small-scale industrial enterprises for domestic private investors. This is also the way of privatization of small and medium-sized industrial plants which emerged as a result of division of large state-owned enterprises consisting of many plants;

- establishment of small and medium-sized industrial plants to be based on crafts, having a very long tradition in manufacturing; the comeback to the market economy is a return to natural conditions of operation for handicraft enterprises; 
- establishment of research and manufacturing enterprises of smallscale industry at universities or in their vicinity; these enterprises should become an important source of innovation, especially in the manufacturing of new products (e.g. scientific-research equipment, medical equipment and equipment for industrial automatics).

A strong private sector of small-scale industry will become a potential partner for foreign investors entering joint ventures in Poland. ${ }^{2}$ This is a very advantageous form of direct foreign investment that enables the launching of production in these enterprises, consisting of combination of their own technological achievements with adaptation of world solutions.

A strong private sector of small-scale industry should also contribute to alleviation of the effects of unemployment.

In 1993 there were $2.7 \mathrm{mln}$ jobless people in Poland, i.e. 14.6\% of total professionally active civil population.

Very high unemployment, as well as threat of its further increase, is recorded in the areas dominated by traditional industries, usually regarded as declining: in Upper Silesia (fuel-engineering and metallurgical industry), Łódź (textile industry), in the Sudetes (fuel-engineering and textile industry), as well as in agricultural regions with predominant state-owned farms undergoing ownership transformation (vast areas in the north).

Lack of the alternative of employment for people dismissed from the enterprises which have become unremunerative, serious indebtedness and often burdensome character for the environment cause that the effects of unemployment in these regions should be alleviated by promotion of smallscale industrial development and the employment on one's own. The latter must be accompanied by local initiative to create new jobs, enliven local economic milieu, enrich the structure of local economy as well as manage free premises left by liquidated industrial and agricultural enterprises.

Some of these regions, especially those lying beyond the sphere of influence of large industrial enterprises, have an unchanged and unpolluted natural environment, enabling the manufacturing of high quality goods by the food, pharmaceutical and electronic industries.

This environment is now becoming a currently important factor of location of small-scale industrial enterprises. This is shown by its large-scale development in attractive landscape regions, i.a. in southern England, California, Bavaria, the Alps and in southern France.

The location factor should be used to make the regions with attractive landscape in Poland economically active. The example of such a region is the southern Pomeranian District, where the natural environment enables

\footnotetext{
2 The absence of this sector is regarded as an important cause of small interest of foreign investors in Polish industry. In over $40 \%$ of the existing joint ventures, the value of direct foreign investment does not exceed 50 thousand dollars, which is equal to the costs of creation of one job in high-technology industries.
} 
production of goods of the highest quality (i.e. in micro-electronics) and where the unemployment rate is twice as high as the country's average.

A strong private sector of small-scale industry will also contribute to the emergence of the Polish middle class, which in highly industrialized countries usually comprises $30-40 \%$ of professionally active population and whose existence is a prerequisite for a stable democracy. 